\title{
Morphometric analysis in basaltic Terrain of Central India using GIS techniques: a case study
}

\author{
Nisha Sahu ${ }^{1}$ - G. P. Obi Reddy ${ }^{1} \cdot$ Nirmal Kumar $^{1}$ - M. S. S. Nagaraju ${ }^{1}$ • \\ Rajeev Srivastava $^{1} \cdot$ S. K. Singh ${ }^{1}$
}

Received: 1 December 2015/Accepted: 14 June 2016/Published online: 24 June 2016

(c) The Author(s) 2016. This article is published with open access at Springerlink.com

\begin{abstract}
Morphometric analysis is significant for investigation and management of the watershed. This study depicts the morphometric analysis of Miniwada Watershed in Nagpur district, Maharashtra, Central India using Geographic Information System (GIS) techniques, which has been carried out through measurement of various aspects like linear, aerial and relief aspects of watershed. The drainage network of the watershed was generated from Cartosat-I DEM $(10 \mathrm{~m})$ using ESRI Software ArcGIS (ver.10.2). The analysis reveals that drainage pattern is dendritic and the stream order in the watershed varies from 1 to 4 . The total number of stream segments of all orders counted as 37 , out of which the majority of orders $(70.27 \%)$ was covered by 1 st order streams and 4 th order stream segments covers only $2.70 \%$. The bifurcation ratio reflects the geological and tectonic characteristics of the watershed and estimated as 3.08. The drainage density of the watershed is $3.63 \mathrm{~km} / \mathrm{sq} \mathrm{km}$ and it indicates the closeness of spacing of channels. The systematic analysis of various parameters in GIS helps in better understanding the soil resources distribution, watersheds prioritization, planning and management.
\end{abstract}

Keywords Central India - Basaltic terrain - Morphometric analysis · Miniwada watershed · GIS · Linear - Areal . Relief aspects

Nisha Sahu

nishasahu5@gmail.com

1 National Bureau of Soil Survey and Land Use Planning, Amravati Road, Nagpur 440 033, India

\section{Introduction}

Proper utilization of available natural resources is vital for development in agriculture, as majority of people depend, directly or indirectly for their livelihood. With the abundant increase in population, it is noticed that water and soil resources need to be managed in an effective manner. The optimal and sustainable development of these resources is prerequisite to avoid any future problems regarding its qualitative and quantitative availability. Water, one of the vital natural resources for agricultural, is becoming deficient because of over-exploitation, poor groundwater recharge, immoderate use etc. Therefore, the study of morphometric characteristics assumes greater significance in developing the surface and groundwater resources more particularly in Central India.

Development of a drainage system and the flowing pattern over space and time are influenced by several variables (Horton 1945; Leopold and Maddock 1953; Abrahams 1984). Many researcher's works were based on arbitrary areas or individual channel segments by considering watershed as a unit. It involves quantitative measurements of the geographic parameters and provides measurement, mathematical analysis of the configuration of the earth's surface as well as shape and dimensions of its landforms and quantitative description of the drainage system, which is an important aspect for the characterization of watersheds (Strahler 1964; Clarke 1966; Agarwal 1998; Sahu et al. 2014). Various hydrological parameters can be correlated with size, shape, slope, drainage density etc. of the drainage basin (Rastogi and Sharma 1976; Magesh et al. 2012). Hence, morphometric analyses provide information related to formation of various processes occurring on the surface of land (Singh 1992, 1995; Reddy et al. 2004a; Dar et al. 2013) which can be better reflected 
through measurement of linear, aerial and relief aspects (Nautiyal 1994; Reddy et al. 2002; Banerjee et al. 2015). It involves the evaluation of stream parameters through the measurements of various stream properties. According to Strahler's system of classification, the stream with no tributaries is designated as first-order, the stream formed by joining two first-order is designated as second -order and so on.

The remote sensing (RS) techniques are convenient for morphometric analysis as a satellite images provide a synoptic view of a large area. The fast emerging spatial information technology, RS, GIS and Global Positioning System (GPS) are effective tools for soil and water resource planning and management rather than conventional methods. The processed Cartosat-I DEM was used successfully to deduce the parameters in GIS environment. RS coupled with GIS techniques have proved to be an efficient tool in drainage delineation and their updation (Pirasteh et al. 2010; Singh et al. 2013, 2014). A number of morphometric studies have been carried out in many parts of the world as well as in different watersheds of India (Chalam et al. 1996; Chaudhary and Sharma 1998; Srinivasan and Subramanian 1999; Kumar et al. 2001; Ali and Singh 2002; Singh et al. 2003; Reddy et al. 2004b) and all have concluded that RS and GIS are powerful tools for studying basin morphometry. Drainage characteristics of many watersheds have been studied using the traditional method, which is laborious and cumbersome (Horton 1945; Strahler 1957, 1964; Krishnamurthy et al. 1996). With the advancement of RS and GIS, the morphometric analysis of natural drain and its drainage network analysis can be better achieved (Farr and Kobrick 2000; Smith and Sandwell 2003; Grohmann 2004; Grohmann et al. 2007) with precise and inexpensive way. Watershed prioritization based on morphometric characteristics has also been carried out and help for locating potential and erosion prone zones (Reddy et al. 2004b; Mishra et al. 2011; Wakode et al. 2011; Romshoo et al. 2012; Jasmin and Mallikarjuna 2013). Drainage morphology along with slope map was also explored for designing water storage structures like percolation tank, pond, check dams etc. Therefore, the main objective of this study is to evaluate various morphometric parameters of the study area using GIS tools.

\section{Study area}

The Miniwada watershed lies between $21^{\circ} 5^{\prime} 47^{\prime \prime}$ to $21^{\circ} 7^{\prime} 26^{\prime \prime} \mathrm{N}$ latitudes and $78^{\circ} 40^{\prime} 41^{\prime \prime}$ to $78^{\circ} 43^{\prime} 26^{\prime \prime} \mathrm{E}$ longitudes in Katol tehsil, the western part of Nagpur district, Maharashtra, Central India. The elevation varies from 407 to $475 \mathrm{~m}$ from mean sea level (MSL) with an area of 1053 ha (Fig. 1). The area is hot subtropical and qualifies for hyperthermic soil temperature regime. The mean annual rainfall is $980 \mathrm{~mm}$, which is lower than the average rainfall of $1205 \mathrm{~mm}$ of Nagpur district. Geologically the area is covered by the spread of basaltic lava flows. Rocks of this region have an aphanitic texture which is the resultant of cooling and the colour range from dark grey to dark greenish grey. In Maharashtra, majority of the area is occupied by Deccan Volcanic Province (DVP), known for their marked horizontality table-topped hills. Basaltic rocks and a typical spheroidal weathering pattern are common in the watershed. The soils of this region have swellingshrinking properties with dendritic drainage pattern.

\section{Methodology}

Survey of India (SOI) toposheet $(55 \mathrm{~K} / 12)$ on 1:50,000 and Cartosat-1 stereo pairs of 3rd March, 2012 with path/row $542 / 299$ have been used for generation of DEM. SOI topographic map $(55 \mathrm{~K} / 12)$ on $1: 50,000$ scale was georeferenced using WGS 84 datum, Universal Transverse Mercator (UTM) zone 44N projection in ArcGIS desktop 10.2.2. For DEM and ortho-image generation from Cartosat-1 stereo pairs, Leica Photogrammetry Suite (LPS) was used in the study. In LPS, Cartosat-I stereo pair images, with both bands were added and automatically tie points were generated. Manually some more tie points were added to reduce error. To check accuracies of all the tie points, triangulation was performed. Ground control points (GCPs) were added manually and again triangulation was carried out. The error was 0.512 which is satisfactory. DEM was generated with a cell size of $10 \mathrm{~m}$ and finally used for ortho rectification using ERDAS Imagine software.

In this study, the Miniwada watershed was delineated and drainage network was extracted using Cartosat-I DEM (10 $\mathrm{m}$ ) in conjunction with Survey of India (SOI) toposheet. The attributes were added to create the digital data base of watershed using ArcGIS. The ridgelines in the toposheet were identified, which act as dividing lines for the runoff (Fig. 2). The stream orders were extracted from Cartosat-I DEM (10 m) and updated from SOI toposheet of 1:50,000 following a system introduced by Horton (1945) but later modified by Strahler (1952). Similarly, the stream length is calculated in GIS platform.

The morphometric parameters analyzed were grouped into three categories related to their orientation in space. They are linear, aerial and relief aspects and calculated based on the formulae shown in Table 1 and the flowchart of the methodology is presented in Fig. 3. 


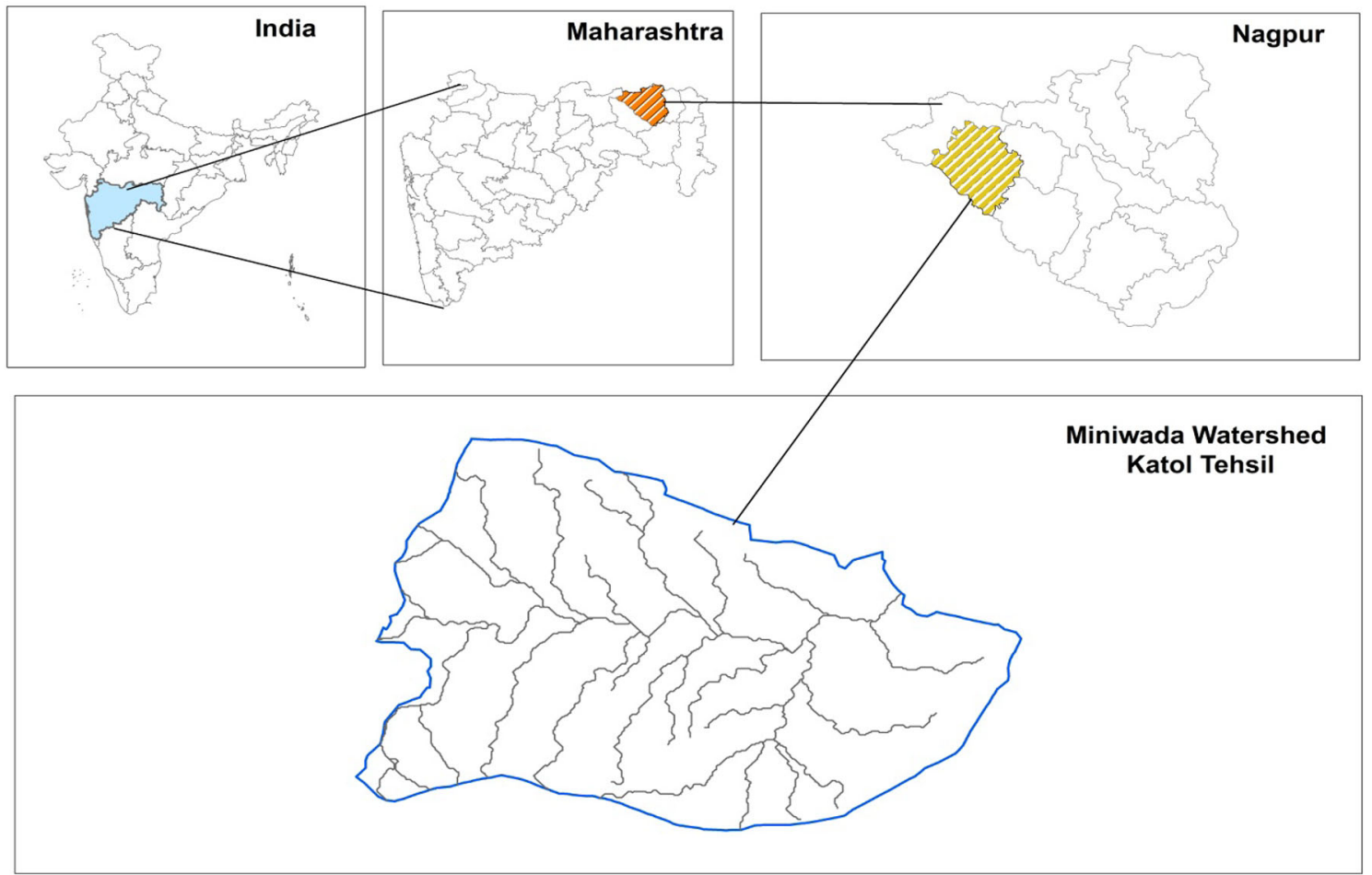

Fig. 1 Location map of study area

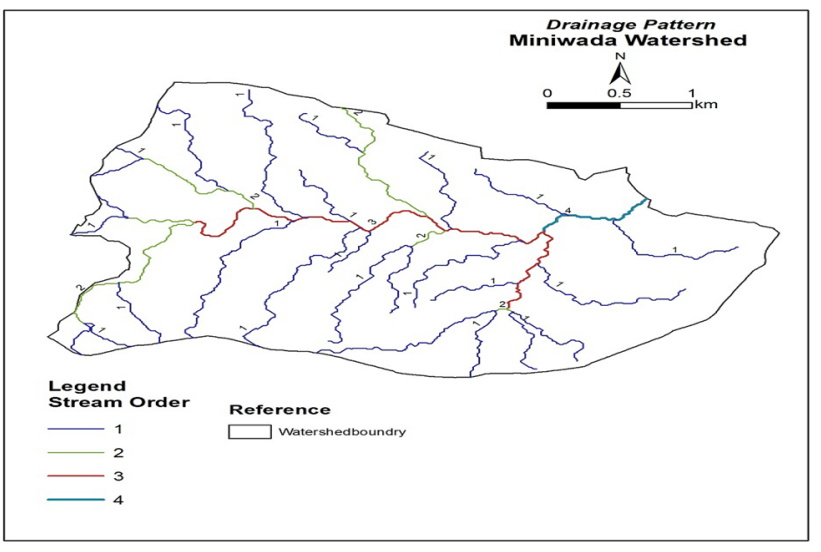

Fig. 2 Digitized drainage map of Miniwada Watershed with stream orders

\section{Results and discussion}

\section{Linear morphometric parameters}

The linear morphometric linear parameters of the watershed were calculated using standard formulae as given in Table 2. Stream order of the watershed is of fourth order (Fig. 2). The details of stream characteristics conform to Horton(1932) "law of stream numbers". Stream number $(\mathrm{Nu})$ supports Horton's law i.e. stream number decreased with increase in stream order in this basin $\left(r^{2}=0.98\right)$, which is quite satisfactory (Fig. 4a) whereas stream length also conforms Horton (1945) second "law of stream length". The length of the stream segments decreased as the stream order increased (Fig. 4b) and it results when basin evolution follows the erosion laws acting on geological material with homogeneous weathering erosion characteristics $\left(r^{2}=0.93\right)$.

In general, the mean stream length (Lsm) of a channel is greater than that of the lower order but this fails in case of second order streams may be due to the slope and topographical variations. The value varied from 0.70 to $2.26 \mathrm{~km}$ and the stream length ratio (RL) of the watershed ranged from 0.44 to 3.22. It has been observed that, there is an increasing trend of RL from lower order to higher order indicating their mature geomorphic stages and if there is a change from one order to another order, it indicates their late youth stage of geomorphic development (Singh and Singh 1997). Abnormal low value (0.44) between third and fourth streams in this study may be an indication that the watershed was subjected to neo-tectonic adjustments, resulting in late youth stage of geomorphic development (Lahiri 1996). In this study, bifurcation ratio $(\mathrm{Rb})$ varied between 3 and 5 and not same from one order to its next order, hence these irregularities are attributed to geological and lithological development of a drainage basin (Strahler 1964). The average value of $\mathrm{Rb}$ is 3.08 , whereas, high $\mathrm{Rb}$ value is the indication of complexity in structure (Nag and 
Table 1 Formulae adopted for computation of morphometric parameters

\begin{tabular}{|c|c|c|c|}
\hline S. no. & Morphometric parameters & Formula/relationship & References \\
\hline \multicolumn{4}{|c|}{ Linear aspects } \\
\hline 1. & Stream order & Hierarchical rank & Strahler (1964) \\
\hline 2. & Stream length & Length of stream & Horton (1945) \\
\hline 3. & Mean stream length & $\begin{array}{l}\mathrm{Lsm}=\mathrm{Lu} / \mathrm{Nu}, \text { where, } \mathrm{Lu}=\text { total stream length of order " } \mathrm{u} \text { ", } \\
\mathrm{Nu}=\text { total no. of stream segments of order } \mathrm{u}\end{array}$ & Strahler (1964) \\
\hline 4. & Stream length ratio & $\begin{array}{l}\mathrm{RL}=\mathrm{Lu} / \mathrm{Lu}-1 \text {, where, } \mathrm{Lu}=\text { total stream length of order "u", } \\
\mathrm{Lu}-1=\text { the total stream length of its next lower order }\end{array}$ & Horton (1945) \\
\hline 5. & Bifurcation ratio & $\begin{array}{l}\mathrm{Rb}=\mathrm{Nu} / \mathrm{Nu}+1, \mathrm{Nu}=\text { total number of stream segments of order } \\
\text { "u", } \mathrm{Nu}+1=\text { number pf stream segments of the next higher } \\
\text { order }\end{array}$ & Schumn (1956) \\
\hline 6. & Mean bifurcation ratio & $\mathrm{Rbm}=$ average of the bifurcation ratio of all order & Strahler (1957) \\
\hline \multicolumn{4}{|c|}{ Aerial aspects } \\
\hline 7. & Drainage texture & $\begin{array}{l}\mathrm{Dt}=\mathrm{Nu} / P, \text { where } \mathrm{Nu} \text { is the total number of streams of all order, } P \text { is } \\
\text { the perimeter of the basin in } \mathrm{km}^{2}\end{array}$ & Horton (1945) \\
\hline 8. & Texture ratio & $\mathrm{Rt}=N 1 / P$, where $N 1$ is the total number of first order streams & Horton (1932) \\
\hline 9. & Drainage density & $\begin{array}{l}\mathrm{D}=\mathrm{Lu} / A, \text { where } A \text { is the total area of the basin }(\mathrm{km})^{2}, \mathrm{Lu} \text { is the total } \\
\text { stream length of all orders }\end{array}$ & Horton (1932) \\
\hline 10. & Stream frequency & $\begin{array}{l}\mathrm{Fs}=\mathrm{Nu} / A, \text { where } \mathrm{Nu} \text { is the total number of streams of all order, } A \text { is } \\
\text { basin area in } \mathrm{km}^{2}\end{array}$ & Horton (1932) \\
\hline 11. & Form factor & $\begin{array}{l}\mathrm{Ff}=A / \mathrm{Lb}^{2} \text { is the square of the basin length }(\mathrm{km}), A \text { is the basin area } \\
\text { in } \mathrm{km}^{2}\end{array}$ & Horton (1932) \\
\hline 12. & Circulatory ratio & $\begin{array}{l}\mathrm{Rc}=4 \pi A / P 2, \text { where } A \text { is the area }(\mathrm{km})^{2} \text { and } p \text { is the perimeter }(\mathrm{km}) \\
\text { of the watershed }\end{array}$ & Miller (1953) \\
\hline 13. & Elongation ratio & $\begin{array}{l}\operatorname{Re}=2 \text { sqrt }(A / \pi) / \mathrm{Lb}, \text { where } A \text { is the area }(\mathrm{km})^{2} \text { and } \mathrm{Lb}=\text { basin } \\
\text { length }\end{array}$ & Schumn (1956) \\
\hline 14. & Length of overland flow & $\operatorname{Lg}=1 /\left(D^{*} 2\right)$, where $D$ is the drainage density & Horton (1945) \\
\hline 15. & Constant channel maintenance & Inverse of drainage density & Schumn (1956) \\
\hline 16. & Shape index & Reciprocal of form factor & Horton (1932) \\
\hline \multicolumn{4}{|c|}{ Relief aspects } \\
\hline 17. & Relief & (Elevation of basin mouth) - (Elevation of highest point on the basin) & Schumn (1956) \\
\hline 18. & Relief ratio & $\begin{array}{l}\mathrm{Rr}=H / \mathrm{Lb}, \text { where } H=\text { total relief (relative relief) of the basin, } \\
\mathrm{Lb}=\text { basin length }\end{array}$ & Schumn (1956) \\
\hline 19. & Ruggedness number & $\begin{array}{l}\mathrm{Rn}=H^{*} D, \text { where } H=\text { watershed relief }(\mathrm{km}), D=\text { drainage density } \\
\quad\left(\mathrm{km} / \mathrm{km}^{2}\right)\end{array}$ & Strahler (1964) \\
\hline
\end{tabular}

Chakroborty 2003). Hence, the watershed might have affected by human activities.

\section{Areal morphometric parameters}

The aerial aspects of the drainage were calculated and results have been shown in Table 3 . The total area of the drainage basin is 1053 ha. The length of the basin is $4402 \mathrm{~m}$. Basin perimeter is the outer boundary of the drainage basin that encloses its area as 20,485 $\mathrm{m}$ using ArcGIS software.

Drainage texture (Dt) is one of the important drainage parameters in morphometric analysis, which depend on numerous factors. According to Smith (1954) drainage density was classified into five classes of drainage texture, i.e. very coarse $(<2)$, coarse $(2-4)$, moderate (4-6), fine (6$8)$ and very fine $(>8)$ drainage texture. The watershed has a value of 1.81 , which falls under very course texture category. The interaction between climate and geology is very well interpreted by drainage density (Ritter and Major 1995). Basin possesses high drainage density i.e. $3.63 \mathrm{~km} /$ $\mathrm{km}^{2}$, which is indicative of less permeable material, sparse vegetative cover and moderate to high relief. The stream frequency of the watershed is 0.04 per ha. Another important factor in the drainage morphometric analysis is texture ratio (Rt) which is found to be 1.27 in the watershed. The circularity ratio of the basin is 0.32 , which is indicative of the lack of circularity and indicates the 
dendritic stage of a watershed. Elongation ratio depicts the shape of the watershed. According to Mustafa and Yusuf (1999), values of elongation ratio ranges from 0.4 to 1.0 and values near to 1.0 are regions of low relief (Strahler 1964). The change in slopes of the watershed can be classified according to Withanage et al. (2014) using elongation ratio, i.e. circular (0.9-0.10), oval (0.8-0.9), less elongated $(0.7-0.8)$, elongated $(0.5-0.7)$, and more elongated (less than 0.5). The elongation ratio of Miniwada watershed is 0.83 and classified as oval. The elongated

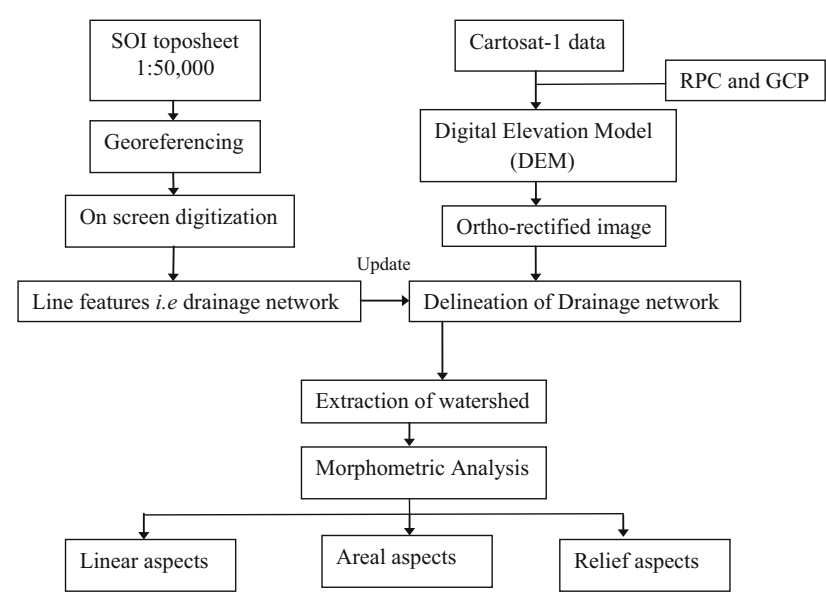

Fig. 3 The flow chart of methodology adopted for morphometric analysis nature of the basin has implication on both hydrologic and geomorphic processes. Mustafa and Yusuf (1999) concluded that the flow of water in elongated shape basins is distributed over a longer period than in circular ones. Elongated in shape indicates less prone to flood, lower erosion and sediment transport capacities. The form factor

Table 3 Aerial and relief aspects of the study area

\begin{tabular}{ll}
\hline Morphometric characteristics & Estimated values \\
\hline Area $(A)$ & $1053 \mathrm{ha}$ \\
Perimeter $(P)$ & $20,485 \mathrm{~m}$ \\
Length of basin (Lb) & $4402 \mathrm{~m}$ \\
Drainage texture (Dt) & 1.81 \\
Texture ratio (Rt) & 1.27 \\
Drainage density (D) & $3.63 \mathrm{~km} / \mathrm{km}^{2}$ \\
Stream frequency (Fs) & $0.04 \mathrm{per} \mathrm{ha}$ \\
Form factor (Ff) & 0.54 \\
Circulatory ratio (Rc) & 0.32 \\
Elongation ratio (Re) & 0.83 \\
Length of overland flow (Lg) & $0.14 \mathrm{~m}$ \\
Constant of channel maintenance $(\mathrm{C})$ & $0.28 \mathrm{~km} / \mathrm{km}$ \\
Shape index (Sb) & 1.84 \\
Relief $(H)$ & $0.07 \mathrm{~km}$ \\
Relief ratio (Rr) & 0.02 \\
Ruggedness number $(\mathrm{Rn})$ & 0.25 \\
\hline
\end{tabular}

Table 2 Linear aspects of the drainage network of the study area

\begin{tabular}{lccccc}
\hline $\begin{array}{l}\text { Stream order } \\
(\mathrm{U})\end{array}$ & $\begin{array}{l}\text { No. of streams } \\
(\mathrm{Nu})\end{array}$ & $\begin{array}{l}\text { Total length of streams } \\
\text { (in m) }\end{array}$ & $\begin{array}{l}\text { Mean stream length } \\
\text { (in m) }\end{array}$ & $\begin{array}{l}\text { Bifurcation ratio } \\
(\mathrm{Rb})\end{array}$ & $\begin{array}{l}\text { Stream length ratio } \\
(\mathrm{RL})\end{array}$ \\
\hline 1 & 26 & $27,085.01$ & 1041.73 & & 0.68 \\
2 & 8 & 5627.75 & 703.47 & 3.25 & 3.22 \\
3 & 2 & 4523.87 & 2261.93 & 4 & 0.44 \\
4 & 1 & 1004.97 & 1004.97 & 2 & 4.34 \\
Total & 37 & $38,241.60$ & 5012.10 & Avg. 3.08 \\
\hline
\end{tabular}

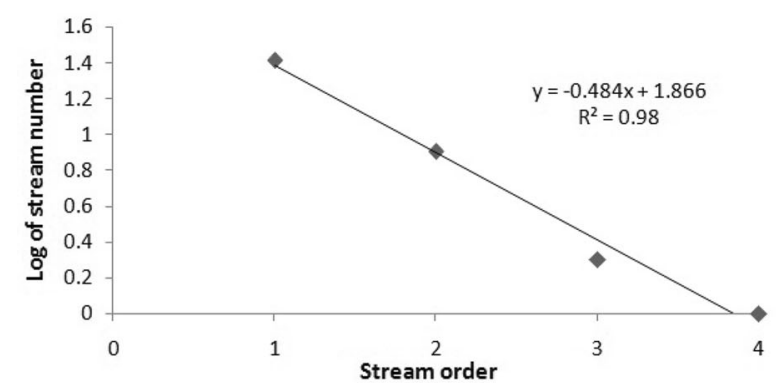

(a)

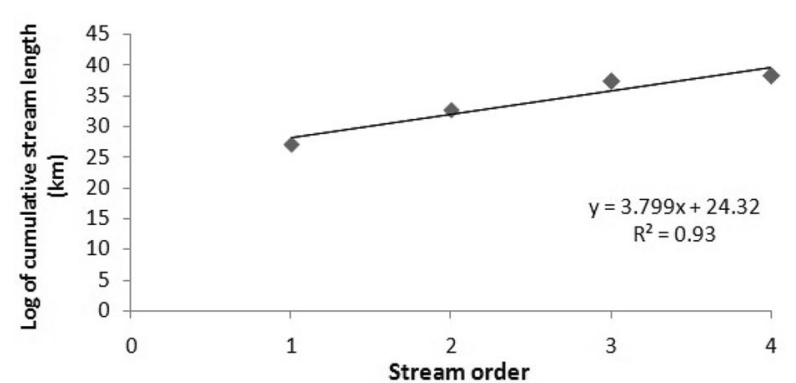

(b)

Fig. 4 a Regression of logarithm of number of streams and stream order, $\mathbf{b}$ regression of logarithm of cumulative stream length and stream order 
(Ff) has the direct relation to the stream flow and the shape of the watershed. In this study, form factor (Ff) of the watershed is 0.54 , which reveals that it is elongated in nature with less side flow for shorter duration and high main flow for a longer duration.

Length of overland flow $(\mathrm{Lg})$ is one of the most important independent variables affecting the development of watershed. Overland flow is significantly affected by infiltration (exfiltration) and percolation through the soil, both varying in time and space and the value of $\mathrm{Lg}$ is 0.14 . The Constant of Channel Maintenance of the basin is 0.28 , which indicates high surface run off. Rate of water and sediment yield along the length and relief of the drainage basin is largely affected by the shape (Reddy et al. 2002). It is the reciprocal of form factor. The shape index values for the watershed is 1.84 .

\section{Relief morphometric parameters}

The relief aspects of the watershed are related with threedimensional features i.e. area, volume and altitude of landforms to analyze different geo-hydrological characteristics. Important relief parameters have been analyzed using standard formulae and results are presented in Table 3. Basin relief is one of the important factor to understand the geomorphic processes involved and landform characteristics. The total basin relief of the drainage basin is $0.07 \mathrm{~km}$. It has been noticed that there is a strong correlation exists between relief and drainage frequency. Relief ratio $(\mathrm{Rr})$ gives indication of overall steepness of a drainage basin and the intensity of erosional process operating on the slope of the basin (Schumn 1956). The value of $\mathrm{Rr}$ is 0.02 , which is low and indicates the presence of basement rocks and moderate relief. Miniwada watershed has a ruggedness number of 0.25 which indicates the regionis less prone to soil erosion.

\section{Conclusion}

The study demonstrates that remote Sensing and GIS have been proved to be efficient and effective tools over conventional methods in the delineation of drainage basin and updating drainage, which is used for the morphometric analysis, geological and geomorphological studies. The quantitative analysis of drainage pattern found to be of immense utility in delineating erosion prone zones which can help to suggest soil and water conservation measures at the parcel level. The computation of linear, areal and relief parameters of the watershed confirm that there is a linear correlation between hydrological behavior and landforms, which is helpful for water management activities. The study reveals that the Miniwada watershed characterized by elongated basin having fourth stream order, high drainage density, low relief ratio and low infiltration with high bifurcation ratio. Drainage network of the watershed is dendritic type and low value of bifurcation ratio indicates that the watershed has suffered less structural disturbance. The high value of elongation ratio compared to circulatory ratio indicates the elongated shape of the watershed, which is mainly due to the guiding effect of thrusting and faulting. The elongated shape of the watershed indicates less prone to flood, lower erosion and sediment transport capacities. The drainage density shows that the area has less vegetative cover and moderate to high relief. Stream frequency and drainage density of the watershed, plays a vital role to control the runoff pattern and other hydrological parameters. Relief ratio reflects that the watershed is treated with soil and water conservation measures. The value of ruggedness number is 0.25 , which is low and shows that the region is less prone to soil erosion. The bifurcation ratio, circulatory ratio and relief ratio have huge significance in deciding the pattern and changes in the shape and drainage of the watershed. The results observed from the analysis could be helpful for watershed prioritization with respect to erosion. In future, drainage morphology along with slope map needs to be explored for locating and selecting the water storage structures like percolation tank, pond, check dams etc. This work shall prove useful and beneficial to the planners and decision makers for proper natural resource management at micro-level.

Open Access This article is distributed under the terms of the Creative Commons Attribution 4.0 International License (http:// creativecommons.org/licenses/by/4.0/), which permits unrestricted use, distribution, and reproduction in any medium, provided you give appropriate credit to the original author(s) and the source, provide a link to the Creative Commons license, and indicate if changes were made.

\section{References}

Abrahams AD (1984) Channel networks: a geomorphological perspective. Water Resour Res 20:161-168

Agarwal CS (1998) Study of drainage pattern through aerial data in Naugarh area of Varanasi district U.P. J Indian Soc Remote Sens 24(4):169-175

Ali S, Singh R (2002) Morphological and hydrological investigation in Hirakund catchment for watershed management planning. J Soil Water Conserv (India) 1(4):246-256

Banerjee A, Singh P, Pratap K (2015) Morphometric evaluation of Swarnrekha watershed, Madhya Pradesh, India: an integrated GIS based approach. Appl Water Sci. doi:10.1007/s13201-0150354-3

Chalam BNS, Krishnaveni M, Karmegam M (1996) Correlation of runoff with geomorphic parameters. J Appl Hydrol 9(3-4):24-31

Chaudhary RS, Sharma PD (1998) Erosion hazard assessment and treatment prioritization of Giri river catchment, North Western Himalaya. Indian J Soil Conserv 26(1):6-11

Clarke JI (1966) Morphometry from maps. Essays in geomorphology. Elsevier Publ. Co., New York, pp 235-274 
Dar RA, Chandra R, Romshoo SA (2013) Morphotectonic and lithostratigraphic analysis of intermontane Karewa basin of Kashmir Himalayas, India. J Mt Sci 10(1):731-741

Farr TG, Kobrick M (2000) Shuttle radar topography mission produces a wealth of data. Am Geophys Union EOS 81:583-585

Grohmann CH (2004) Morphometric analysis in geographic information systems: applications of free software GRASS and R. Comput Geosci 30:1055-1067

Grohmann CH, Riccomini C, Alves FM (2007) SRTM-based morphotectonic analysis of the Pocos de caldas alkaline massif Southeastern Brazil. Comput Geosci 33:10-19

Horton RE (1932) Drainage basin characteristics. Trans Am Geophys Union 13:350-361

Horton RE (1945) Erosional development of streams and their drainage basins; hydrophysical approach to quantitative morphology. Geol Soc Am Bull 56:275-370

Jasmin I, Mallikarjuna P (2013) Morphometric analysis of Araniar river basin using remote sensing and geographical information system in the assessment of groundwater potential. Arab J Geosci 6(10):3683-3692

Krishnamurthy J, Srinivas G, Jayaram V, Chandrasekhar MG (1996) Influence of rock type and structure in the development of drainage networks in typical hard rock terrain. ITC J 3/4:252-259

Kumar R, Lohani AK, Kumar S, Chatterjee C, Nema RK (2001) GIS based morphometric analysis of Ajay river basin up to Sarath gauging site of South Bihar. J Appl Hydrol 15(4):45-54

Lahiri S (1996) Channel pattern as signature of neotectonic movements-a case study from Brahmaputra Valley in Assam. J Indian Soc Remote Sens 24(4):265-272

Leopold LB, Maddock T (1953) The hydraulic geometry of stream channels and some physiographic implications. USGS professional paper 252:1-57

Magesh NS, Chandrasekar N, Kaliraj S (2012) A GIS based automated extraction tool for the analysis of basin morphometry. Bonfring Int J Ind Eng Manag Sci 2(1):32-35

Miller VC (1953) A quantitative geomorphic study of drainage basin characteristics in the Clinch Mountain area, Virginia and Tennessee. Proj. NR 389-402. Tech Rep 3, Columbia University, Department of Geology, ONR, New York

Mishra A, Dubey DP, Tiwari RN (2011) Morphometric analysis of Tons basin, Rewa District, Madhya Pradesh, based on watershed approach. Earth Sci India 4(3):171-180

Mustafa S, Yusuf MI (1999) A textbook of hydrology and water resources, I edn. Jenas Prints and Publishing Company, Abuja (Chapter 5)

Nag SK, Chakroborty S (2003) Influence of rock types and structures in the development of drainage networks in hard rock area. J Indian Soc Remote Sens 31(1):25-35

Nautiyal MD (1994) Morphometric analysis of drainage basin using aerial photographs, a case study of Khairkuli basin, District Dehradun, U.P. J Indian Soc Remote Sens 22(4):251-261

Pirasteh S, Safari HO, Pradhan B, Attarzadeh I (2010) Lithomorphotectonics analysis using Landsat ETM data and GIS techniques: Zagros Fold Belt (ZFB), SW Iran. Int Geoinformatics Res Dev J $1(2): 28-36$

Rastogi RA, Sharma TC (1976) Quantitative analysis of drainage basin characteristics. J Soil Water Conserv India 26(14):18-25

Reddy GPO, Maji AK, Gajbhiye KS (2002) GIS for morphometric analysis of drainage basins. GIS India 11(4):9-14
Reddy GPO, Maji AK, Gajbhiye KS (2004a) Drainage morphometry and its influence on landform characteristics in Basaltic Terrain-a remote sensing and GIS approach. Int J Appl Earth Obs Geoinform 6:1-16

Reddy GPO, Maji AK, Chary GR, Srinivas CV, Tiwary P, Gajbhiye KS (2004b) GIS and remote sensing applications in prioritization of river sub basins using morphometric and USLE parametersa case study. Asian J Geoinform 4(4):35-49

Ritter FE, Major NP (1995) Useful mechanisms for developing simulations for cognitive models. AISB Q 91:7-18

Romshoo SA, Bhat SA, Rashid I (2012) Geoinformatics for assessing the morphometric control on hydrological response at watershed scale in the Upper Indus basin. J Earth Syst Sci 121(3):659-686

Sahu N, Reddy GPO, Kumar N, Nagaraju MSS, Srivastava R, Singh SK (2014) Characterization of landforms and land use/land cover in basaltic terrain using IRS-P6 LISS-IV and Cartosat-1 DEM data: a case study. Agropedology 24(2):166-178

Schumn SA (1956) Evaluation of drainage systems and slopes in badlands at Perth Amboy, New Jersy. Bull Geol Soc Am 67:597-646

Singh S (1992) Quantitative geomorphology of the drainage basin. In: Chouhan TS, Joshi KN (eds) Readings on remote sensing applications. Scientific Publishers, Jodhpur

Singh S (1995) Quantitative analysis of watershed geomorphology using remote sensing techniques. Ann Arid Zone 34(4):243-251

Singh S, Singh MC (1997) Morphometric analysis of Kanhar River Basin. Natl Geogr J India 43(1):31-43

Singh RK, Bhatt CM, Hari Prasad V (2003) Morphological study of a watershed using remote sensing and GIS techniques. J Hydrol 26(1-2):55-66

Singh P, Thakur J, Singh UC (2013) Morphometric analysis of Morar River Basin, Madhya Pradesh, India using remote sensing and GIS techniques. Environ Earth Sci 68:1967-1977

Singh P, Gupta A, Singh M (2014) Hydrological inferences from watershed analysis for water resource management using remote sensing and GIS techniques. Egypt J Remote Sens Space Sci 17:111-121

Smith KG (1954) Standards for grading texture of erosional topography. Am J Sci 248:655-668

Smith B, Sandwell D (2003) Accuracy and resolution of shuttle radar topography mission data. Geophys Res Lett 30(9):20-21

Srinivasan PR, Subramanian V (1999) Ground water targeting through morphometric analysis in Mamundiyar river basin, Tamilnadu. Deccan Geogr 37(1):22-23

Strahler AN (1952) Hypsometric analysis of erosional topography. Bull Geol Soc Am 63(11):1117-1142

Strahler AN (1957) Quantitative analysis of watershed geomorphology. Trans Am Geophys Union 38:913-920

Strahler AN (1964) Quantitative geomorphology of drainage basin and channel networks. Hand book of applied hydrology. McGraw Hill, New York (section 4-11)

Wakode HB, Dutta D, Desai VR, Baier K, Azzam R (2011) Morphometric analysis of the upper catchment of Kosi River using GIS techniques. Arab J Geosci 6(2):395-408

Withanage NS, Dayawansa NDK, Silva RP (2014) Morphometric analysis of the Gal Oya river basin using spatial data derived from GIS. Trop Agric Res 26(1):175-188 